\title{
Perisynaptic Chondroitin Sulfate Proteoglycans Restrict Structural Plasticity in an Integrin-Dependent Manner
}

\author{
Clara Orlando, ${ }^{1}$ Jeanne Ster, ${ }^{1}$ Urs Gerber, ${ }^{1}$ James W. Fawcett, ${ }^{2}$ and Olivier Raineteau ${ }^{1}$ \\ ${ }^{1}$ Brain Research Institute, University of Zürich/Eidgenössische Technische Hochschule, 8057 Zürich, Switzerland, and ${ }^{2}$ Brain Repair Centre, University of \\ Cambridge, CB2 OPY Cambridge, United Kingdom
}

During early postnatal development of the CNS, neuronal networks are configured through the formation, elimination, and remodeling of dendritic spines, the sites of most excitatory synaptic connections. The closure of this critical period for plasticity correlates with the maturation of the extracellular matrix (ECM) and results in reduced dendritic spine dynamics. Chondroitin sulfate proteoglycans (CSPGs) are thought to be the active components of the mature ECM that inhibit functional plasticity in the adult CNS. These molecules are diffusely expressed in the extracellular space or aggregated as perineuronal nets around specific classes of neurons. We used organotypic hippocampal slices prepared from 6-d-old Thy1-YFP mice and maintained in culture for 4 weeks to allow ECM maturation. We performed live imaging of CA1 pyramidal cells to assess the effect of chondroitinase ABC (ChABC)-mediated digestion of CSPGs on dendritic spine dynamics. We found that CSPG digestion enhanced the motility of dendritic spines and induced the appearance of spine head protrusions in a glutamate receptor-independent manner. These changes were paralleled by the activation of $\beta 1$-integrins and phosphorylation of focal adhesion kinase at synaptic sites, and were prevented by preincubation with a $\beta 1$-integrin blocking antibody. Interestingly, microinjection of ChABC close to dendritic segments was sufficient to induce spine remodeling, demonstrating that CSPGs located around dendritic spines modulate their dynamics independently of perineuronal nets. This restrictive action of perisynaptic CSPGs in mature neural tissue may account for the therapeutic effects of ChABC in promoting functional recovery in impaired neural circuits.

\section{Introduction}

The early postnatal development of the CNS is characterized by a critical period for plasticity during which circuits are shaped and connections refined in an experience-dependent manner (Knudsen, 2004; Hensch, 2005). This plasticity is associated with dynamic processes involving the formation, elimination, and remodeling of dendritic spines, the sites of excitatory synaptic connections. In rodents, the critical period for plasticity closes early after birth and marks a decline in spines dynamics. In parallel, the juvenile type of extracellular matrix (ECM) is replaced by its mature form that persists throughout adulthood (Frischknecht and Gundelfinger, 2012). Proteolysis of the mature ECM restores spine plasticity suggesting a role for the ECM in stabilizing dendritic spines.

Chondroitin sulfate proteoglycans (CSPGs) are the main components of the mature ECM. As the critical period comes to

\footnotetext{
Received May 18, 2012; revised Sept. 18, 2012; accepted 0ct. 18, 2012.

Author contributions: C.O.,U.G.,J.W.F., and 0.R. designed research; C.O and J.S. performed research; C.O. and J.S. analyzed data; C.O. and O.R. wrote the paper.

This work was supported by Internationale Stiftung für Forschung in Paraplegie, Zürich, Grant P91; The Christopher and Dana Reeve Foundation; and The Isaac Newton Trust of the University of Cambridge. We are grateful to D. Göckeritz-Dujmovic and S. Carta for excellent technical assistance with slice cultures preparation and microinjections. We also thank F. Christ for providing Thy1-YFP mice and J. Kwok for providing CSPG antibodies. We thank B. H. Gähwiler, G. Locatelli, and R. Fiorelli for valuable discussions.

The authors declare no competing financial interests.

Correspondence should be addressed to either Dr. Olivier Raineteau or Clara Orlando, Brain Research Institute, University of Zürich/Eidgenössische Technische Hochschule, Winterthurerstrasse 190, 8057 Zürich, Switzerland. E-mail: raineteau@hifo.uzh.ch or orlando@hifo.uzh.ch.

DOI:10.1523/JNEUROSCI.2406-12.2012

Copyright $\odot 2012$ the authors $\quad 0270-6474 / 12 / 3218009-09 \$ 15.00 / 0$
}

an end, these proteins undergo changes in their core composition, in sulfation patterns and in distribution (Deepa et al., 2006; Miyata et al., 2012), forming a diffused ubiquitous matrix as well as dense perineuronal nets (PNNs) mainly surrounding parvalbumin-expressing fast-spiking interneurons (Härtig et al., 1999). In vivo digestion of CSPGs mediated by the bacterial enzyme chondroitinase $\mathrm{ABC}(\mathrm{ChABC})$ restores functional plasticity in various models of CNS pathologies (Kwok et al., 2011); however, the mechanisms mediating these effects are still poorly understood. In particular, while most attention has been focused on PNNs, the role of the diffused ECM in controlling CNS structural plasticity has been so far neglected. Nevertheless, the ECM that fills perisynaptic spaces surrounding dendritic spines may play an important role in restricting the remodeling of neuronal circuits at the synaptic level.

We explored the effects of ChABC-mediated CSPG digestion on dendritic spine dynamics by performing live imaging in mature hippocampal slice cultures. We could show that ChABC treatment has effects independent of PNN digestion that lead to enhanced motility of dendritic spines and to the formation of spine head protrusions. These dynamic changes are driven by $\beta 1$-integrin activation and phosphorylation of focal adhesion kinase (FAK) at synaptic sites.

\section{Materials and Methods}

Organotypic slice cultures. Organotypic slice cultures of hippocampus were prepared from Thyl-YFP pups (H-line; The Jackson Laboratory) or wild-type $\mathrm{Bl} / 6$ at postnatal day 6 as previously described (Gähwiler et al., 
Table 1. List of primary reagents/antibodies used for immunofluorescence

\begin{tabular}{|c|c|c|c|}
\hline Reagent/antibody & Species & $\begin{array}{l}\text { Dilution and incubation } \\
\text { time }\end{array}$ & Catalog\#/company \\
\hline Parvalbumin & Mouse & 1:5000 (3d) & PV235/Swant \\
\hline WFA-biotin & - & 1:500 (1 d) & B-1355/Vector Laboratories \\
\hline Proteoglycan Di-4S, 2B6 & Mouse & $1: 700(3 d)$ & 270432/Seikagaku \\
\hline Aggrecan & Mouse & $1: 400(1 \mathrm{~d})$ & $\begin{array}{l}\text { MAB5284/Millipore Bioscience } \\
\text { Research Reagents }\end{array}$ \\
\hline Versican & Mouse & $1: 5(1 \mathrm{~d})$ & Clone 12C5/DSHB \\
\hline Brevican & Rabbit & $1: 300(1 d)$ & ab111719/Abcam \\
\hline Neurocan & Mouse & $1: 500(1 \mathrm{~d})$ & $\begin{array}{l}\text { MAB5212/Millipore Bioscience } \\
\text { Research Reagents }\end{array}$ \\
\hline Phosphacan & Mouse & $1: 30(1 d)$ & Clone 3F8/DSHB \\
\hline$\beta 1$-Integrins & Mouse & $1: 60(3 d)$ & MAB1987Z/Millipore \\
\hline Active $\beta 1$-integrins & Mouse & $1: 250(3 d)$ & MAB2079Z/Millipore \\
\hline FAK & Rabbit & $1: 125(3 d)$ & AH00502/Invitrogen \\
\hline Phospho-FAK (Y397) & Rabbit & $1: 125(3 d)$ & 44-625G/Invitrogen \\
\hline PSD-95 & Mouse & $1: 250(3 d)$ & $\begin{array}{l}\text { MA1-045/Thermo Fisher } \\
\text { Scientific }\end{array}$ \\
\hline DAPI & - & $1: 10,000$ (5 min) & D3571/Invitrogen \\
\hline T0-PRO-3 & - & $1: 20,000$ (3 min) & T3605/Invitrogen \\
\hline
\end{tabular}

1997) and maintained in roller tubes for periods ranging from 1 to 5 weeks. Culture medium (50\% Basal Medium Eagle, 25\% inactivated horse serum, 25\% HBSS, $5.6 \mathrm{~mm}$ glucose, and $200 \mathrm{~mm}$ L-glutamine) was changed every week. Slices gradually mature to form stable circuits whose development resembles, both in terms of timing and connectivity, the in vivo situation (Muller et al., 1993; De Simoni et al., 2003; Cho et al., 2007). This model is well suited for performing chronic treatments and long-term imaging.

Enzymatic treatment. Digestion of CSPGs was achieved by treatment with protease-free ChABC from Proteus vulgaris (Seikagaku). ChABC was reconstituted in $0.1 \mathrm{~m}$ phosphate buffer $(\mathrm{PB})(0.1 \mathrm{U} / \mu \mathrm{l}), \mathrm{pH} 7.4$, before being added to the culture medium. Slices were treated with ChABC $(0.5 \mathrm{U} / \mathrm{ml})$ for $4 \mathrm{~h}$. Sham-treated slices (control) were treated with $0.1 \mathrm{M} \mathrm{PB}, \mathrm{pH}$ 7.4. For long-term treatment ( $\mathrm{LtT}$ ), slices were incubated with the enzyme $(0.25 \mathrm{U} / \mathrm{ml})$ for $24 \mathrm{~h}$. The bacterial enzyme Penicillinase (matched for protein content; Sigma-Aldrich) was used as a control enzyme. To achieve local CSPG digestion, ChABC was diluted to a pipette concentration of $0.1 \mathrm{U} / \mu \mathrm{l}$ in artificial CSF (ACSF) immediately before use. The enzyme was applied locally by pressure using a glass micropipette positioned in the stratum radiatum of CA1 field at $50 \mu \mathrm{m}$ from the imaged dendrite. Ejection pressure was set at $70 \mathrm{mbar}$ with a pulse duration of $50 \mathrm{~ms}$. HCS CellMask Deep Red stain (Invitrogen) was included in the pipette to monitor the ejection. After slice fixation, traces of the dye in the tissue were used to localize the injection site (see Fig. $5 B$ ) and the digestion area. Effective CSPG digestion was confirmed by staining for proteoglycan disaccharide 4-sulfate, with an antibody (2B6) that recognizes disaccharide units $(\Delta-\mathrm{di}-4 \mathrm{~S})$ that remain attached to the core proteins ("stubs") after ChABC has digested most of the glycosaminoglycan (GAG) chains but does not recognize intact CSPGs (Moon et al., 2001). Wisteria floribunda agglutinin (WFA) was used to visualize PNNs and to further confirm the enzymatic digestion (as absence of staining in the digestion area). Digested CSPGs and intact PNNs were visualized with Alexa Fluor 488 (green) and streptavidin 555 (red), respectively. Imaged dendrites located $50 \mu \mathrm{m}$ far from the ejection site but not included in the digestion area were used as control (see Fig. 5B).

Immunofluorescence. Slice cultures were fixed for $1 \mathrm{~h}$ in $4 \%$ formaldehyde at room temperature. After blocking in $0.1 \mathrm{M} \mathrm{PB}$ supplemented with $0.4 \%$ Triton X-100 (0.1 M PB-TX) and 10\% inactivated normal horse serum for $2 \mathrm{~h}$ at room temperature, slices were incubated with primary reagent/antibodies (see complete list as well as dilution and incubation time in Table 1 ) at $4^{\circ} \mathrm{C}$. After several washes in $0.1 \mathrm{M}$ PB-TX, slices were incubated with streptavidin (streptavidin Alexa Fluor 555; $4 \mu \mathrm{g} / \mathrm{ml}$; Invitrogen) or species-matched secondary antibodies (anti-mouse Alexa Fluor 488, anti-mouse Alexa Fluor 555, anti-rabbit Alexa Fluor 555, antimouse Alexa Fluor 647, anti-rabbit Alexa Fluor 647; all $4 \mu \mathrm{g} / \mathrm{ml}$; Invit- rogen) for $2 \mathrm{~h}$ at room temperature. Slices were counterstained with DAPI (Invitrogen) or TO-PRO-3 (Invitrogen), washed in $0.1 \mathrm{M} \mathrm{PB}$, and mounted onto gelatin-coated slides with Vectashield mounting medium (Reactolab) to preserve fluorescent labeling.

Western blot. Slices were quickly removed from the glass coverslips, placed in $50 \mu \mathrm{l}$ of ice-cold extraction buffer ( $20 \mathrm{~mm}$ Tris- $\mathrm{HCl} ; 0.5 \%$ CHAPS; Complete protease inhibitors; Roche) and homogenized manually. Homogenates were incubated on ice for $60 \mathrm{~min}$ before centrifugation at $13,200 \mathrm{rpm}\left(15 \mathrm{~min}, 4^{\circ} \mathrm{C}\right)$ and extraction of the supernatant. Protein measurements were performed using the Bio-Rad protein assay (Bio-Rad). SDS-PAGE was performed in $4-12 \%$ polyacrylamide gels under reducing conditions. Proteins were transferred to PVDF membranes (Immobilon; catalog \#IPVH00010; Millipore) at $4^{\circ} \mathrm{C}$ for $90 \mathrm{~min}$ at $130 \mathrm{~V}$. Membranes were washed twice in TBS containing $0.1 \%$ Tween 20 (TBS-T) and blocked with 5\% skimmed milk in TBS-T for $30 \mathrm{~min}$. Blots were then incubated overnight in TBS-T with $1 \%$ skimmed milk containing the antibody mouse anti-proteoglycan 4-sulfate disaccharides (2B6; 1:1000; Seikagaku). Membranes were washed three times in TBS-T and incubated for $90 \mathrm{~min}$ in TBS-T containing peroxidase-conjugated antimouse antibody (1:10,000; Vector Laboratories). Membranes were washed three times and proteins were visualized using a chemiluminescent substrate (Thermo Fisher Scientific). GAPDH was used as loading control and protein normalization. In this preparation, the antibody 2B6 recognizes digested chondroitin 4-sulfate glycosaminoglycan chains on three proteoglycan core proteins within the region of the blot spanning $160-300 \mathrm{kDa}$ (see Fig. 2C).

Drug application. To block ionotropic glutamate receptors, the following drug mixture was added to the culture medium before imaging: ChABC plus D-2-amino-5-phosphonopentanoate (D-AP5) (40 $\mu \mathrm{M})$ plus 2,3-dihydroxy6-nitro-7-sulfamoyl-benzo[f]quinoxaline-2,3-dione (NBQX) (25 $\mu \mathrm{M})$. For studying the role of integrins in spine dynamics, slices were pretreated with a functional $\beta 1$-integrin blocker (MAB1987Z; Millipore) or ACSF (control) overnight. Briefly, the $\beta 1$-integrin blocker was diluted to a pipette concentration of $0.1 \mathrm{mg} / \mathrm{ml}$ in ACSF immediately before use. The antibody or ACSF was locally applied by pressure using a glass micropipette (tip diameter of 12 $\mu \mathrm{m})$ in the stratum radiatum of CA1 field. Pressure was set at 70 mbar and 35 $\mathrm{nl} / \mathrm{min}$ antibody solution was injected. Phenol Red dye was included in the pipette to monitor the ejection. The following day, slices were treated with ChABC or PB $0.1 \mathrm{~m}$ before imaging.

Time-lapse imaging. Time-lapse imaging was performed on apical dendrites of first and second branching order of CA1 pyramidal neurons in the stratum radiatum. Time-lapse series were collected with a Leica TCS SP5 confocal inverted microscope (Leica Microsystems) equipped with a perfusion system and temperature controller $\left(37^{\circ} \mathrm{C}\right)$. During the imaging session, slices were constantly superfused with $\operatorname{ACSF}\left(37^{\circ} \mathrm{C}\right)$ containing $12 \mathrm{~mm} \mathrm{NaCl}, 0.3 \mathrm{~mm} \mathrm{KCl}, 2.4 \mathrm{~mm} \mathrm{CaCl}_{2}, 1.2 \mathrm{~mm} \mathrm{MgCl}, 2.3$ mu NaHCO, $0.12 \mathrm{~mm} \mathrm{NaH}_{2} \mathrm{PO}_{4}$, and $5.5 \mathrm{~mm}$ glucose. Dendritic spines were visualized by using the $488 \mathrm{~nm}$ laser line, with a $63 \times / 1.3$ glycerol immersion long working distance objective and an additional magnification of $8 \times$. To capture rapid dynamic events, stacks of $25-30$ optical sections $(512 \times 512$ pixels $)$ were collected every minute for $20 \mathrm{~min}$. The $z$-step size between optical sections was $0.2 \mu \mathrm{m}$. The same settings were used for local microinjection of ChABC. In this case, stacks of the selected dendrite were acquired before injection to set the baseline values. After injection, time-lapse series of $20 \mathrm{~min}$ were acquired at intervals of $10 \mathrm{~min}$ for a total recording time of $2 \mathrm{~h}$. Images were deconvolved using Huygens Software (by Scientific Volume Imaging) and analyzed with ImageJ (http://rsb.info.nih.gov/ij/). Spine density was measured on threedimensional projections and defined as the number of spines per $10 \mu \mathrm{m}$ of dendritic length. Spine head circularity was estimated using the shape factor method as previously described (Verkuyl and Matus, 2006). Spines exhibiting spine head protrusions (SHPs) were excluded from the shape factor measurement. Spine length was measured from the base of the spine to its tip, and the motility index was calculated for each spine based on the average absolute change in length per unit time. Spine lengths and motility index were measured on two-dimensional projections. This method of analysis underestimates spine dynamics, since movements in the $z$-direction are not considered, but improves image contrast and measurement accuracy. Exclusively spines with a clearly distinguishable 


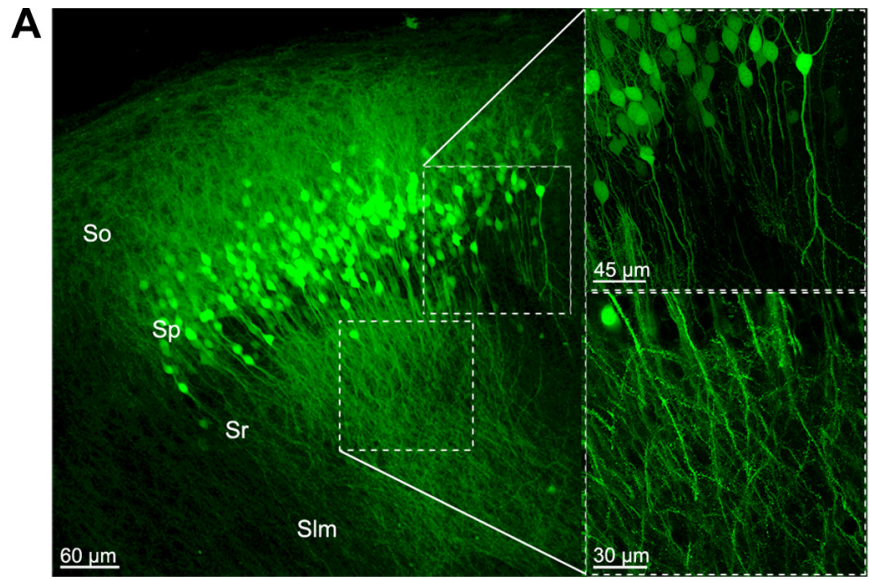

Figure 1. Thy1-YFP expression in hippocampal organotypic slice cultures after 4 weeks in vitro. $A, 0$ verview of the CA1 field. A subpopulation of pyramidal neurons is labeled by YFP in their entirety, including somata, axons, dendrites, and dendritic spines. So Stratum oriens; Sp, stratum pyramidale; Sr, stratum radiatum; SIm, stratum lacunosum moleculare. $\boldsymbol{B}$, Deconvolved image of a dendritic segment in stratum radiatum (maximal intensity projection of a stack of 25 images, $0.2 \mu \mathrm{m} z$-step size). In 4-week-old slices, dendritic spines showed mature morphologies (i.e., stubby, thin, and mushroom).

neck and head were considered. The percentage of motile spines was estimated in every group considering the total number of spines with a motility index higher that the average motility index of the control group. SHPs were counted along the entire dendrite in $3 \mathrm{D}$ and given as number of spines making SHPs per $10 \mu \mathrm{m}$ of dendritic length. All values are presented as the mean \pm SEM. Statistical analyses were performed using Student's $t$ test.

Electrophysiology. After 4 weeks in vitro, slice cultures were treated with ChABC or $0.1 \mathrm{M}$ PB before being transferred to a recording chamber on an upright microscope (Axioscope FS; Zeiss). Slices were superfused continuously with ACSF $\left(1 \mathrm{ml} / \mathrm{min} ; 33^{\circ} \mathrm{C}\right)$. Whole-cell voltage-clamp recordings were obtained from CA1 pyramidal cells held at $-70 \mathrm{mV}$ with an Axopatch 200A amplifier (Molecular Devices). Recording pipettes (4-6 M $\Omega$ ) were filled with $135 \mathrm{~mm} \mathrm{~K}$-gluconate, $5 \mathrm{~mm} \mathrm{KCl,} 10 \mathrm{~mm}$ HEPES, 1 mM EGTA, 5 mm phosphocreatine, 2 mm MgATP, $0.4 \mathrm{~mm}$ $\mathrm{NaGTP}$, and $0.07 \mathrm{~mm} \mathrm{CaCl}_{2}$. Miniature EPSCs (mEPSCs) were filtered at $2-5 \mathrm{kHz}$ and analyzed off-line (pClamp 10). This program detects events that exceed an arbitrary threshold (typically set at $8-15 \mathrm{pA}$ ) for a minimum length of time (1 ms). All values are presented as the mean \pm SEM. Statistical analyses were performed using the unpaired $t$ test. The identity of pyramidal neurons was confirmed after recording by intracellular labeling with biocytin and morphological analyses.

Imaging of fixed tissue. Images of fixed tissue were acquired using a Leica TCS SPE II confocal microscope (Leica Microsystems). Number and area of puncta positive for postsynaptic density-95 (PSD-95), FAK, $\beta 1$-integrin, phosphorylated FAK, and active $\beta 1$-integrin subunits were automatically measured with Imaris 7.0 (Bitplane) at a final magnification of $500 \times$. Colocalization analysis were performed in a blind fashion with LAS AF software (Leica Microsystems). Optical density of CSPGs in the stratum radiatum was automatically measured with LAS AF software (Leica Microsystems). All values are presented as the mean \pm SEM. Statistical analyses were performed using Student's $t$ test (Prism, version 3.02; GraphPad)

\section{Results}

Maturation of dendritic spines and ECM in hippocampal slice cultures

In a first series of experiments, we tested the suitability of organotypic hippocampal slice cultures prepared form Thy1-YFP mouse pups as an experimental model for imaging of dendritic spines after ChABC treatment. Over a period of 4 weeks, a subpopulation of CA1 pyramidal neurons became YFP-positive, allowing visualization of their entire processes and dendritic spines that gradually acquired the mature morphologies (i.e., stubby,

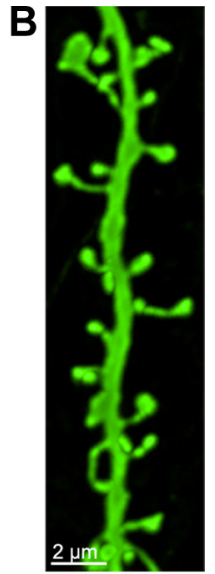

thin, and mushroom) characteristic of the adult rodent brain (Fig. $1 A, B$ ). Staining of 4-week-old slices with the lectin WFA revealed a distribution pattern of GAG chains typical of the adult CA1 region (Brückner et al., 2003), with mild staining of the neuropil in stratum radiatum and stratum lacunosum moleculare and intensely stained PNNs in the stratum oriens and pyramidale (Fig. 2A). Similarly to in vivo (Härtig et al., 1999), CSPG-enriched PNNs developed around parvalbumin-expressing nonpyramidal neurons (Fig. 2A) and could first be detected after $7 \mathrm{~d}$ in vitro (DIV), corresponding to $13 \mathrm{~d}$ after birth (Fig. $2 \mathrm{C}$ ). The density of PNNs increased thereafter to reach values comparable with adult mice after 28 and 35 DIV, highlighting the gradual maturation of the tissue. In the CA1 stratum oriens and pyramidale of 4-week-old slices, PNNs were labeled by antibodies against aggrecan, versican, brevican, and phosphacan, but not neurocan (Fig. 2B). Optical density analysis further confirmed a similar expression pattern of these CSPGs in the stratum radiatum of 28 DIV hippocampal slices when compared with fixed slices collected from age-matched animals (Fig. 2C). Comparable with in vivo, aggrecan and versican were the most abundant CSPGs in this stratum. Two regimes of ChABC treatment (i.e., short-term and long-term) (see Materials and Methods) were equally efficient in digesting the GAG chains of CSPGs in mature slices as reflected by a complete loss of WFA binding sites (data not shown), and the detection of digested proteoglycan 4-sulfate disaccharides with the antibody 2B6 in slice lysates (Fig. 2D). Together, these data illustrate the suitability of long-term slice cultures for studying dendritic spine dynamics after experimental manipulation of the ECM.

\section{$\mathrm{CnABC}$ treatment enhances spine dynamics in a glutamate receptor-independent manner}

We next assessed the effects of ChABC-mediated CSPG digestion on spine dynamics. Time-lapse imaging of dendritic spines of CA1 pyramidal neurons after $\mathrm{ChABC}$ treatment revealed a significant and persistent increase in spine motility (control, 146 spines, 14 cells, 8 slices; ChABC, 151 spines, 20 cells, 11 slices; $p<$ 0.01 ; LtT, 148 spines, 17 cells, 9 slices; $p<0.001$ ), when compared with sham-treated slices (Fig. $3 B$ ). On average, ChABC treatment induced a twofold increase in the percentage of motile spines (Fig. 3D). Spine length (control, 146 spines, 14 cells, 8 slices; ChABC, 151 spines, 20 cells, 11 slices; $p>0.06$; LtT, 148 spines, 17 cells, 9 slices; $p>0.2$ ), spine head circularity (control, 132 spines, 14 cells, 8 slices; ChABC, 155 spines, 20 cells, 11 slices; $p>$ 0.06 ; LtT, 150 spines, 17 cells, 9 slices; $p>0.2$ ), and mean spine density (control, 14 cells, 8 slices; ChABC, 20 cells, 9 slices; $p>$ 0.9 ; LtT, 16 cells, 8 slices; $p>0.5$ ) were unaltered by CSPG digestion. Thus, in our model, ChABC-mediated CSPG digestion rapidly and persistently enhanced motility of preexisting spines. In parallel to these changes, we observed a long-lasting increase in the appearance of SHPs in ChABC-treated compared with control slices (number of SHPs/ $10 \mu \mathrm{m}$ : control, $0.5 \pm 0.06,16$ cells, 9 slices; ChABC, $1.03 \pm 0.09,30$ cells, 10 slices; $p<0.001$; LtT, $0.85 \pm 0.06,17$ cells, 8 slices; $p<0.001$; Fig. $3 E)$. SHPs appeared 
A

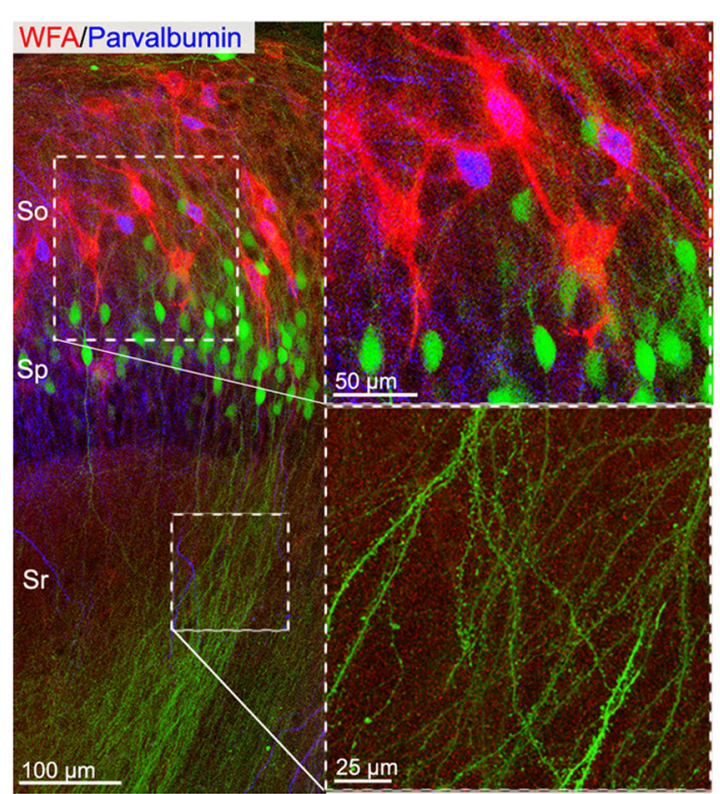

B
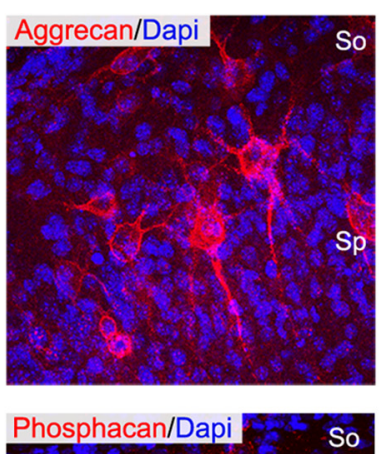

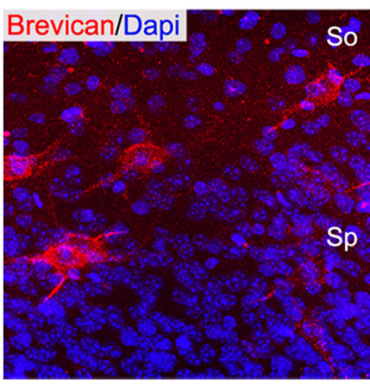

Versican/Dapi
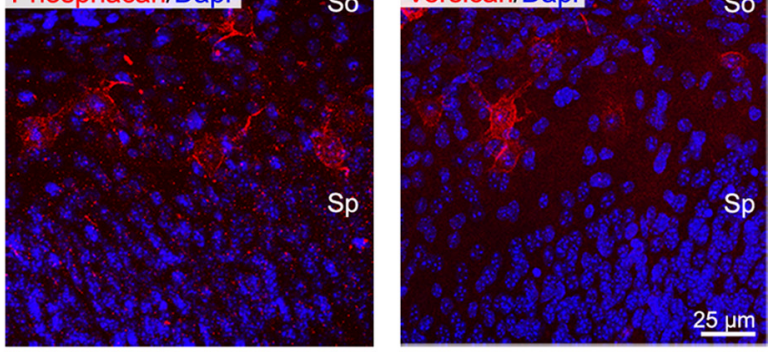

C

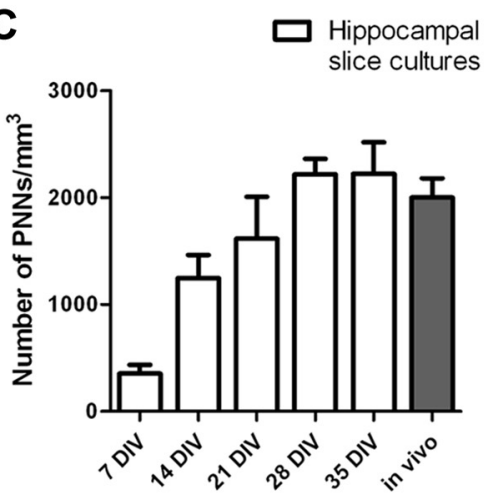

\begin{abstract}
In vivo
\end{abstract}
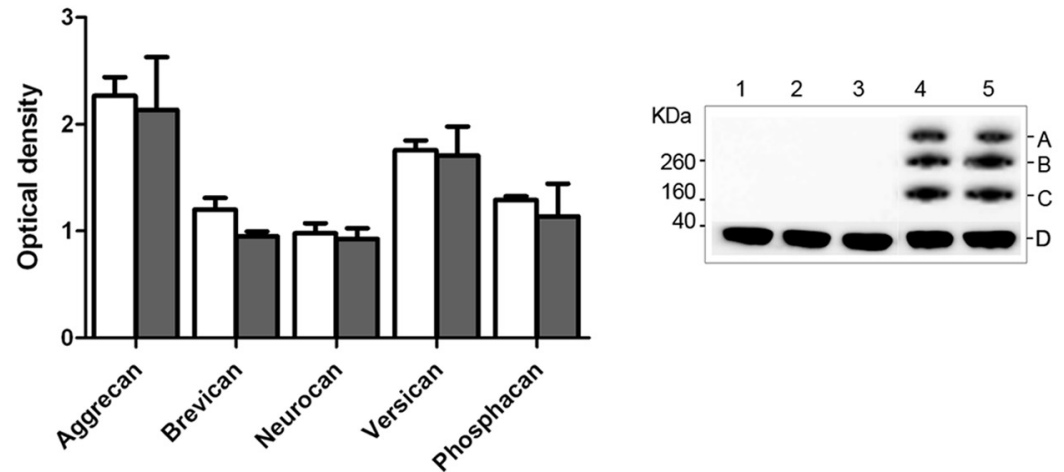

Figure 2. Distribution and digestion of CSPGs in long-term hippocampal organotypic slices. A, Hippocampal organotypic slices (after 28 DIV) were stained with WFA (red) to reveal CSPGs diffusely distributed around YFP-positive CA1 pyramidal dendrites in stratum radiatum (Sr), or aggregated in PNNs around parvalbumin-positive interneurons (blue) in stratum oriens (So) and pyramidale (Sp). B, Aggrecan, brevican, versican, and phosphacan-positive PNNs (red) were detected in 4-week-old slices in CA1 stratum oriens (So) and pyramidale (Sp). DAPI was used to visualize the strata. C, In slice cultures, the density of WFA-positive PNNs increased over time and became comparable with that observed in vivo in 8-week-old mice. Optical density analysis of immunostaining for CSPGs in the stratum radiatum of hippocampal slice cultures (28 DIV, white bars, 4 slices/protein) compared with fixed tissues from 5-week-old mice (gray bars; $n=3$ mice). As in vivo, aggrecan and versican are the most abundant CSPGs in the stratum radiatum. $\boldsymbol{D}$, Western blot of slice lysates shows digested chondroitin 4-sulfate glycosaminoglycan chains on three core proteins (bands $\mathrm{A}-\mathrm{C}$ ) after ChABC treatment, reflecting efficient CSPG digestion. Band D: GAPDH; 1, control; 2, penicillinase (control enzyme) long-term treatment; 3, penicillinase short-term treatment; 4, ChABC long-term treatment; 5 , ChABC short-term treatment. Error bars indicate SEM.

as filopodia-like extensions emanating from a spine head, occasionally exhibiting a terminal swelling (Fig. $3 A$, white arrows). In contrast to a previous report linking the appearance of SHPs to glutamate spillover (Richards et al., 2005), treatment with ChABC in presence of the glutamatergic receptor blockers D-AP5 $(40 \mu \mathrm{M})$ and NBQX $(25 \mu \mathrm{M})$ did not prevent SHP emergence (Fig. 3E). Thus, ChABC-induced SHP formation is independent of changes in glutamatergic transmission, which was confirmed by electrophysiological measurements of synaptic transmission. Whole-cell patch-clamp recordings from CA1 pyramidal cells revealed no differences in frequency (control, $0.6 \pm 0.2 \mathrm{~Hz}, 7$ cells; ChABC, $0.6 \pm 0.04 \mathrm{~Hz}, 6$ cells; $p>0.8$ ) and amplitude (control, $-13.1 \pm 0.8 \mathrm{pA}, 7$ cells; ChABC, $-13.3 \pm 1 \mathrm{pA}, 6$ cells; $p>0.8$ ) of mEPSCs after ChABC or sham treatment. Similarly, the rise time (control, $1.60 \pm 0.1 \mathrm{~ms}, 7$ cells; ChABC $1.62 \pm 0.13$ $\mathrm{ms}, 6$ cells; $p>0.8$ ) and the decay time (control, $3.3 \pm 0.3 \mathrm{~ms}, 7$ cells; ChABC $3.61 \pm 0.46 \mathrm{~ms}, 6$ cells; $p>0.5$ ) of mEPSCs did not change after CSPG digestion, indicating that ChABC triggered structural plasticity by enhancing spine dynamics without modifying synaptic transmission.

\section{CSPG digestion increases integrin signaling at synaptic sites}

To gain insight into the mechanisms mediating ChABC-induced enhancement of spine dynamics, we investigated the potential role of integrins, a family of transmembrane proteins that interact with several ECM components. In the hippocampus, $\beta 1$ integrin subunits are present in the majority of spines (Pinkstaff et al., 1999; Mortillo et al., 2012). In agreement with a previous in vitro study showing an inhibition of $\beta 1$-integrins by CSPGs (Tan et al., 2011), ChABC treatment enhanced activation and clustering of $\beta 1$-integrins without altering $\beta 1$-integrin expression levels, as revealed by immunostaining ( 5 slices/group; active $\beta 1$ integrin number and area, $p<0.01$; native $\beta 1$-integrin number, $p>0.4$; area, $p>0.9$; Fig. $4 A$ ). Phosphorylation of the tyrosine 
A

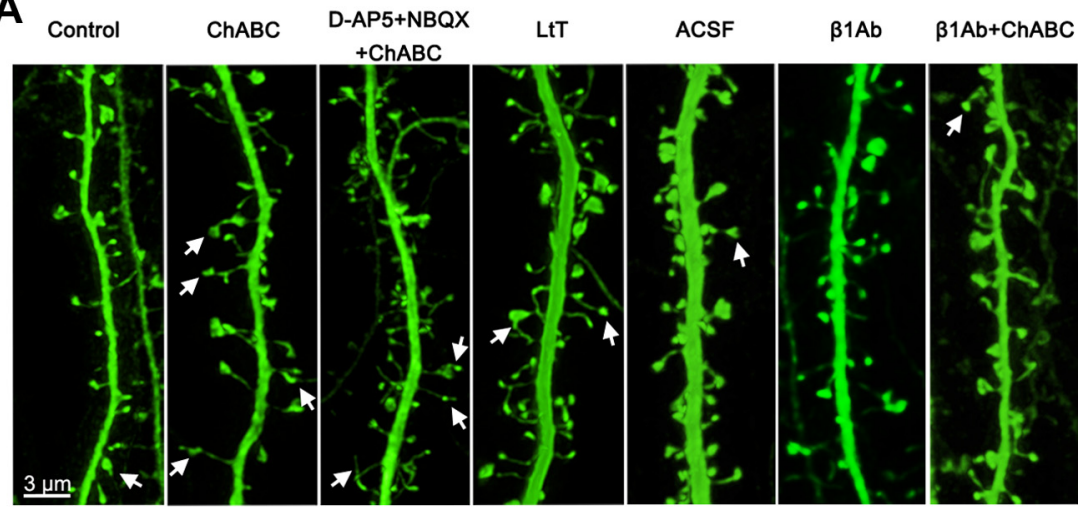

B

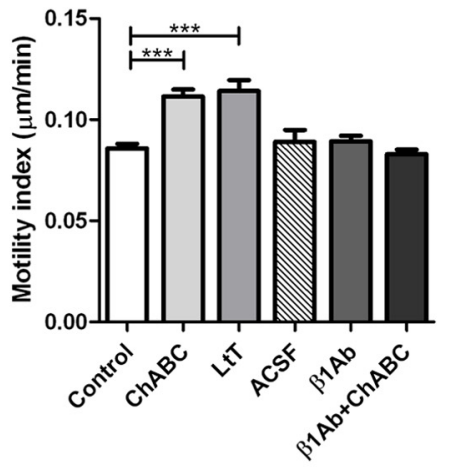

D

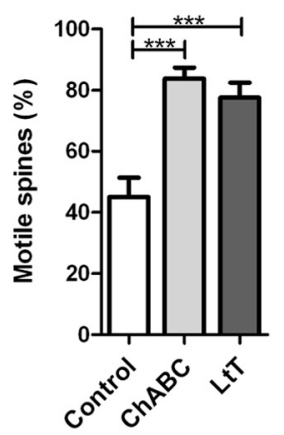

C

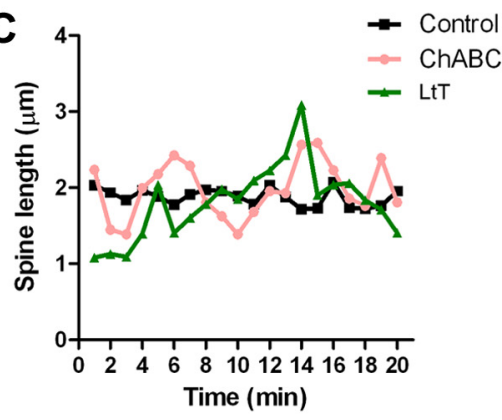

E

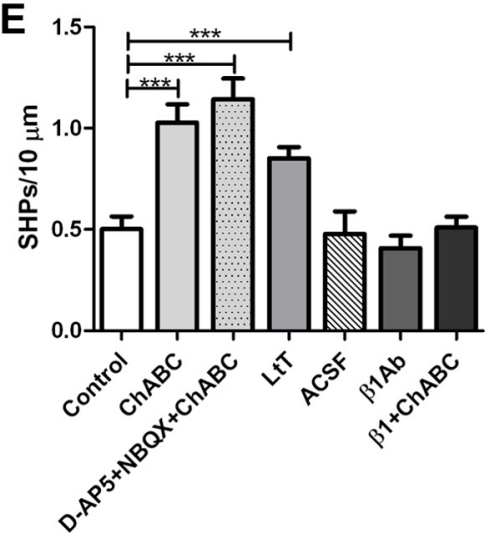

Figure 3. CSPG digestion-induced enhancement of spine dynamics is dependent on $\beta 1$-integrins. $A$, Representative confocal images of living YFP-positive CA1 pyramidal apical dendrites in the different treatment conditions. The white arrows indicate SHPs. $B$, ChABC-mediated enhancement of spine motility was blocked by pretreatment with a $\beta 1$-integrin blocking antibody. C, Fluctuations in length over time for representative spines. The average spine length was not affected by ChABC treatment. D, CSPG digestion resulted in a doubling of the percentage of motile spines. Spines were considered motile when the respective motility index was higher than the average motility index of the control group. $\boldsymbol{E}$, ChABC induced the formation of SHPs. Blocking of glutamatergic receptors failed to inhibit formation of SHPS, while pretreatment with a $\beta 1$-integrin blocking antibody prevented their appearance. LtT, Long-term treatment; ACSF, artificial CSF microinjection; $\beta 1 \mathrm{Ab}, \beta 1$-integrin blocking antibody microinjection; $\beta 1 A b+C h A B C$, $\beta 1$-integrin blocking antibody microinjection followed by ChABC treatment. ${ }^{* * *} p<0.001$, Student's $t$ test. Error bars indicate SEM.

kinase FAK is one of the earliest signaling events upon integrin activation and clustering that transduces extracellular cues to the cytoskeleton (Mitra et al., 2005). In agreement, active $\beta 1$ integrin-positive puncta were often associated with phosphorylated FAK puncta in CA1 stratum radiatum (Fig. $4 B$, white arrows) after ChABC treatment. The number of phosphorylated FAK puncta was enhanced in CAl stratum radiatum after ChABC treatment, with no differences in the level of native FAK compared with control slices (number of phosphorylated FAK puncta, $p<0.01 ; 10$ slices; number of native FAK puncta, $p>0.9$;

5 slices; Fig. 4A,D). Phosphorylated FAKpositive puncta were detected in association with YPF-positive spines and the synaptic marker PSD-95 (Fig. 4C). The number and volume of PSD-95 puncta remained unchanged in ChABC-treated compared with control slices (number, $p>0.9$; volume, $p>0.4$; Fig. $4 A, B)$. A higher percentage of phosphorylated FAK-positive puncta colocalized with PSD-95 could, however, be observed after ChABC treatment (control, 41.28\%; ChABC, 60.1\%; $p<0.001$; Fig. 4D). Together with the stability of spine density and volume (see above), these data indicate that $\mathrm{ChABC}$ treatment activates $\beta 1$ integrin and its downstream effector FAK within a stable spine population. Thus, CSPG integrity prevents integrin activation and signaling at synaptic sites.

To directly assess the involvement of this signaling pathway on spine dynamics, we injected a function neutralizing $\beta 1$ integrin-specific antibody into the stratum radiatum before ChABC treatment. Under these conditions, CSPG digestion no longer enhanced spine motility (ACSF, 163 spines, 6 cells, 4 slices; $\beta 1 \mathrm{Ab}, 292$ spines, 20 cells, 5 slices; $p>0.9$; $\beta 1 \mathrm{Ab}+\mathrm{ChABC}, 577$ spines, 35 cells, 9 slices, vs ACSF, $p>0.2$, vs $\beta 1 \mathrm{Ab}, p>0.09$; Fig. $3 A, B$ ) or SHP formation (ACSF, 6 cells, 4 slices; $\beta 1 \mathrm{Ab}, 20$ cells, 5 slices, $p>0.5$; $\beta 1 \mathrm{Ab}+\mathrm{ChABC}, 35$ cells, 9 slices, vs ACSF, $p>0.7$, vs $\beta 1 \mathrm{Ab}, p>0.2$; Fig. $3 A, E)$. We therefore conclude that ChABC treatment enhanced spine dynamics via integrin activation.

\section{CSPG-mediated restriction of spine dynamics is independent of PNNs} CSPGs are expressed homogeneously throughout the ECM. In addition, they aggregate as PNNs around fast-spiking parvalbumin-positive interneurons in our in vitro model as occurs in vivo (Fig. $2 A$ ). While these structures have been involved in restricting functional plasticity, the role of perisynaptic CSPGs in the control of spine structural plasticity remains elusive. Thus, to specifically digest perisynaptic CSPGs, while preserving the integrity of PNNs, we performed local microinjections of ChABC in the stratum radiatum (Fig. $5 \mathrm{~A}$ ) followed by imaging of spine dynamics. As revealed by staining of proteoglycan disaccharide 4-sulfate (2B6) and GAG chains (WFA) on imaged slices after fixation, this approach resulted in digestion of GAG chains in an area restricted to the apical dendrites (Fig. $5 B, C$, white arrows). The dye HCS CellMask Deep Red stain (Invitrogen) was included in the pipette to monitor the ejection and to help subsequent localization of the digested area after slice fixation (Fig. 5A, before ejection; $B$, after slice fixation, blue). Similarly to the increased spine dy- 
A

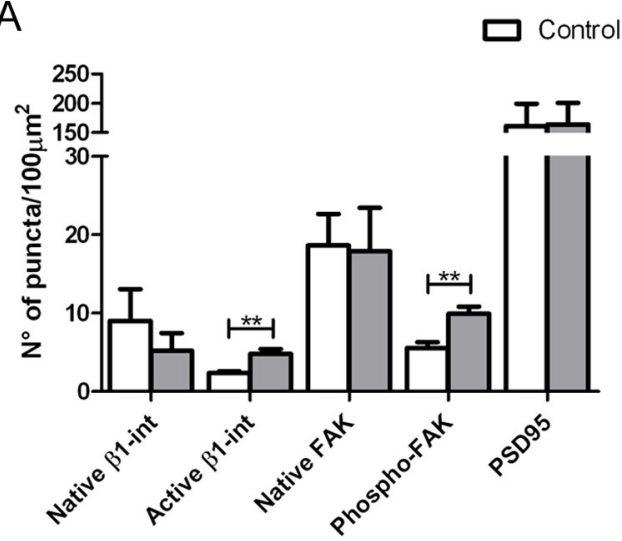

B

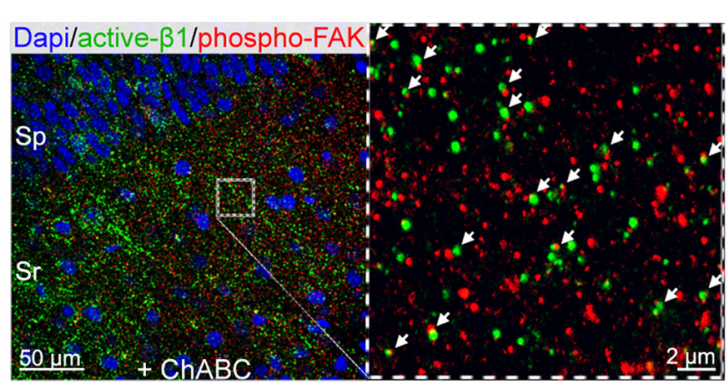

$\mathrm{D}$

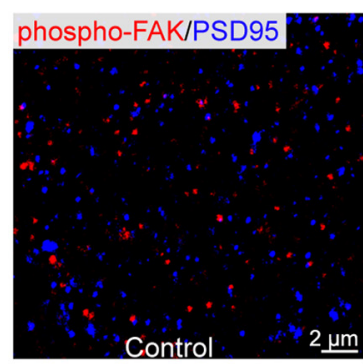

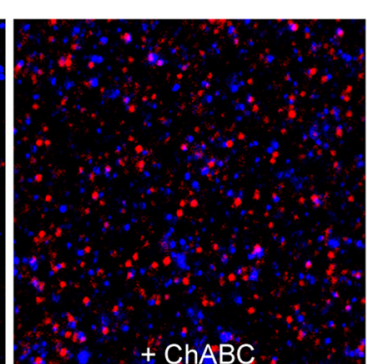

ChABC

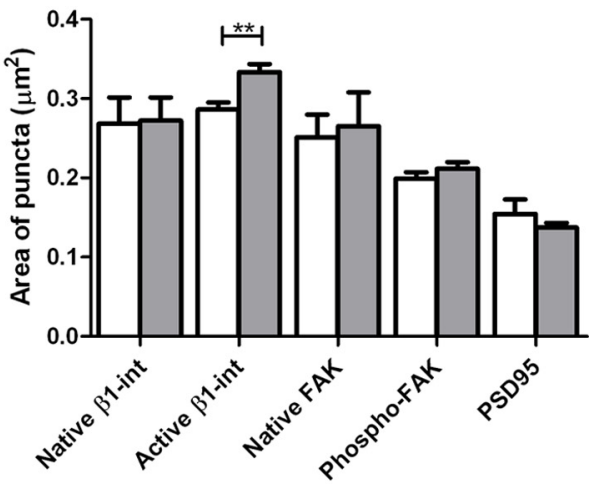

C
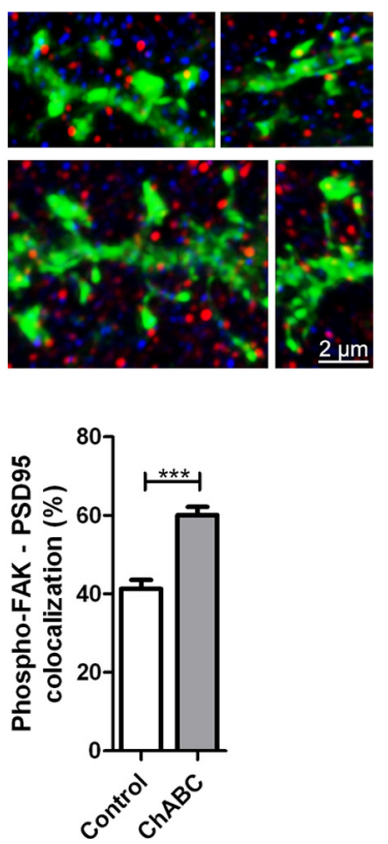

Figure 4. CSPG digestion promotes activation of $\beta 1$-integrins and phosphorylation of FAK. $A, A$ higher density of active $\beta 1$-integrins and phosphorylated FAK-positive puncta was detected within the CA1 stratum radiatum after ChABC treatment compared with control slices (active $\beta 1$-int: control, $2.35 \pm 0.27$ puncta, 5 slices; ChABC, $4.81 \pm 0.7$ puncta, 5 slices; phospho-FAK: control, $5.5 \pm 0.76$ puncta, 10 slices; $(\mathrm{hABC}, 9.9 \pm 0.93$ puncta, 10 slices). ChABC treatment did not change the level of expression of native FAK and $\beta 1$-integrin. Active $\beta 1$-integrin puncta were significantly larger in treated slices compared with control slices (control, $0.28 \pm 0.01 \mu \mathrm{m}^{2}, 5$ slices; ChABC, $0.33 \pm 0.01 \mu \mathrm{m}^{2}, 5$ slices). $B$, Active $\beta 1$-integrin-positive puncta were often associated with phosphorylated FAK-positive puncta in CA1 stratum radiatum after ChABC treatment. DAPI staining was used to visualize the CA1 strata. The white arrows indicate active $\beta 1$-integrin-positive puncta (green) colocalizing with phosphorylated FAK-positive puncta (red). C, In ChABC-treated slices, phosphorylated FAK-positive puncta (red) were detected in association with YFP-positive dendritic spines (green) and the synaptic marker PSD-95 (blue). On average, $60.1 \pm 2.09 \%$ of phosphorylated FAK puncta colocalized with PSD-95 puncta after CSPGs digestion compared with $41.28 \pm 2.26 \%$ in control slices. D, High-magnification images show phosphorylated FAK-positive puncta (red) and PSD-95-positive puncta (blue) in the stratum radiatum of the CA1 field in control and ChABC-treated slices. ${ }^{* *} p<0.01,{ }^{* * *} p<0.001$, Student's $t$ test. Error bars indicate SEM.

namics reported above, enhancement of spine motility and formation of SHPs were observed throughout the $2 \mathrm{~h}$ recording period in treated but not in control dendrites (control, 4 dendrites; ChABC, 9 dendrites; Fig. 5D-F). The motility of control spines was enhanced $10 \mathrm{~min}$ after injection as a mechanical response to the manipulation, but rapidly recovered to basal levels (Fig. 5E). These results indicate that CSPGs surrounding dendritic spines directly restrict spine dynamics and that the degradation of their glycosaminoglycan chains promotes their structural plasticity independently of PNN digestion.

\section{Discussion}

In this study, we present evidence that structural plasticity of dendritic spines is restricted by CSPGs. Their digestion by the enzyme ChABC resulted in increased spine dynamics that was dependent on activation of $\beta 1$-integrins. Notably, these effects were independent of PNN degradation, as local digestion of perisynaptic CSPGs was sufficient to induce similar structural changes as those observed after global ECM digestion.

Several studies have demonstrated a role for ChABC treatment in promoting functional plasticity in models of CNS pathologies (Bradbury et al., 2002; Pizzorusso et al., 2002; Gogolla et al., 2009; Kwok et al., 2011). The underlying mechanisms have, however, remained unclear. As mechanistic studies are difficult to perform at the synaptic level in vivo, we made use of a highly accessible and well established in vitro model (i.e., mouse hippocampal organotypic cultures). This model offers the advantage of being able to perform chronic treatments and long-term imaging, two prerequisites for completion of the present study. 
A

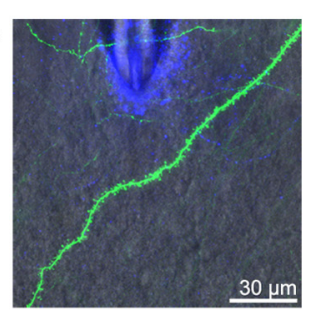

\section{B}

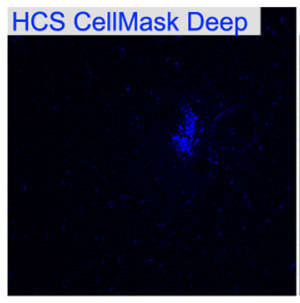

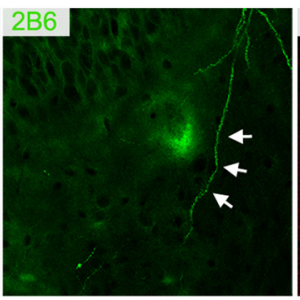


C
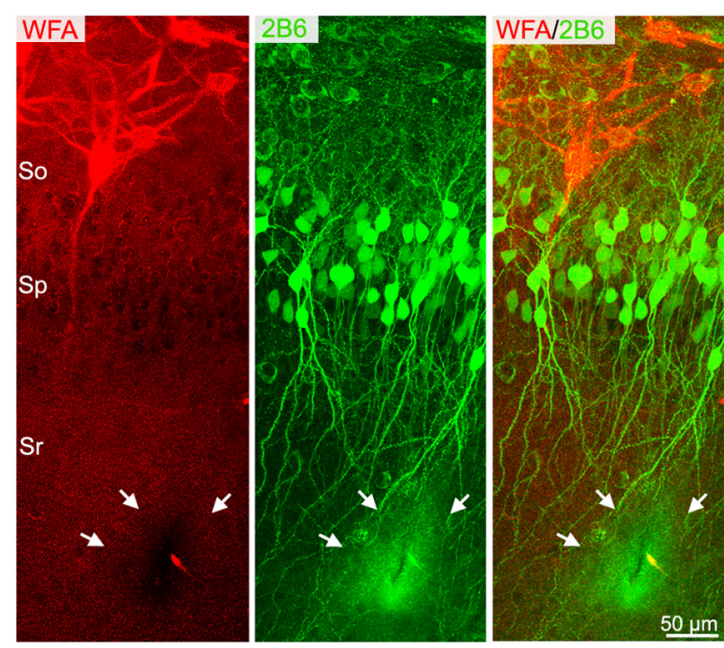

D
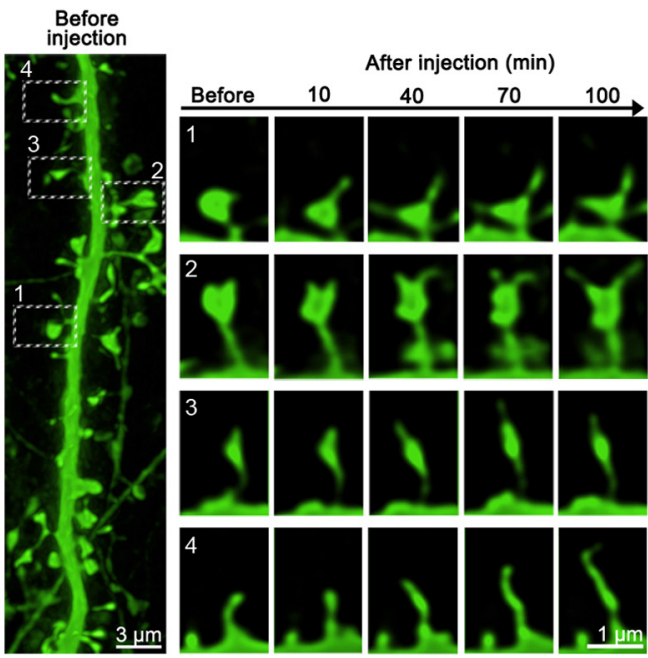

$\mathbf{E}$

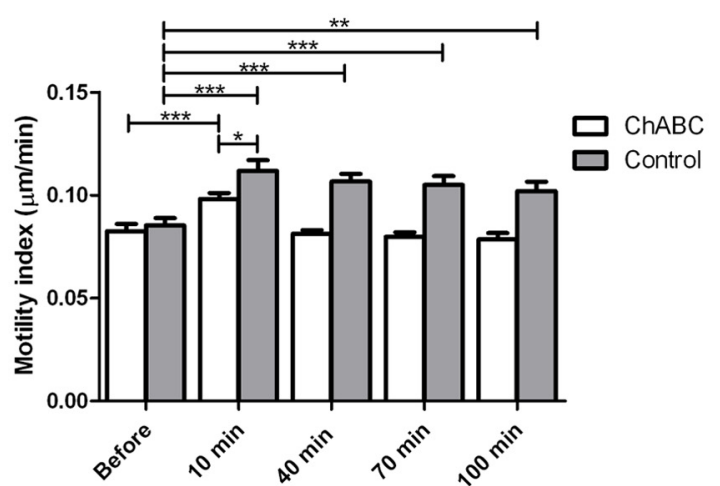

$\mathbf{F}$



Figure 5. Local CSPG digestion around selected dendritic segments is sufficient to enhance spine dynamics. $A, C \mathrm{ChAB}$ was microinjected in the stratum radiatum (Sr). A glass micropipette was positioned in the stratum radiatum of the CA1 field at $50 \mu \mathrm{m}$ from the imaged dendrite (green). HCS CellMask Deep Red stain (blue) was included in the pipette to monitor the ejection. $\boldsymbol{B}$, Example of imaged dendrites located $50 \mu \mathrm{m}$ far from the ejection site but not included in the digestion area and used as control (white arrows indicate the dendrite). Effective CSPG digestion was confirmed by staining with the antibody 2B6 (green) and WFA (red). C, This approach resulted in the successful digestion of CSPG around segments of apical dendrites as revealed by positive staining for proteoglycan 4-sulfate disaccharides in the stratum radiatum (2B6; green staining highlighted by white arrows) and loss of WFA binding sites inside the digestion area, while preserving the integrity of PNNs (WFA, red) in stratum oriens (So) and pyramidale (Sp). D, SHPs appeared on both thin and mushroom spine subtypes shortly after local CSPG digestion and persisted for the entire recording period (i.e., 2 h). $\boldsymbol{E}, \boldsymbol{F}$, Local ChABC injection enhanced spine motility $(\boldsymbol{E})$ and induced SHPs $(\boldsymbol{F})$ only on dendritic segments included in the digestion area. ${ }^{*} p<0.05$, ${ }^{* *} p<0.01$, ${ }^{* * *} p<0.001$, Student's $t$ test. Error bars indicate SEM.

While slice cultures prepared from adult mice are prone to rapid degeneration (Cho et al., 2007), slices prepared from early postnatal animals show long-term survival and gradually mature to form stable circuits whose development resembles the in vivo situation. Furthermore, synaptic transmission, dendritic morphology, and details of spine shape development and density in slices cultures have been shown to be equivalent to brain slices (Muller et al., 1993; Gähwiler et al., 1997; De Simoni et al., 2003; Cho et al., 2007). In particular, dendritic spine density peaks during the third postnatal week and remain constant thereafter, with spines acquiring the typical morphologies observed in the adult rodent brain (Muller et al., 1993; Boyer et al., 1998). Our results further expand those previous reports by showing that
ECM maturation, in particular the gradual appearance of WFApositive PNNs, follows in organotypic slices the timing, pattern of development, and CSPG composition observed in vivo. These data are consistent with a normal maturation of ECM in organotypic slice cultures.

Previous studies using proteases for degrading the mature ECM have shown that adult neuronal tissue retains some potential for structural and functional plasticity at the level of dendritic spines (Oray et al., 2004; Wang et al., 2008; Michaluk et al., 2011). Unlike proteases that degrade a large number of ECM proteins, ChABC principally catalyzes the removal of GAG chains of CSPGs, where most of the inhibitory activity of these glycoproteins is localized (García-Alías and Fawcett, 2012). Using this 
enzyme, we could show that CSPG removal promotes structural plasticity by enhancing dendritic spine motility and formation of spine head protrusions. Restriction of spine dynamics may be mediated by the negatively charged sulfate groups of the chondroitin sulfate GAG chains, as suggested by recent work identifying changes in the sulfation pattern of CSPGs as a determinant in terminating the critical period for plasticity (Miyata et al., 2012). Short- and long-term treatment with ChABC resulted in the same amount of digested CSPGs and in comparable enhancement of spine dynamics. The low rate of CSPG de novo production and the stable activity of the enzyme might account for these long-lasting effects. These observed effects are likely to be mediated by digestion of aggrecan and versican around dendritic spines. Among lecticans, these two proteoglycans have the largest core protein size and are enriched in GAG chains (Galtrey and Fawcett, 2007). Our immunostaining reveal that aggrecan and versican are the most abundant CSPGs in the stratum radiatum.

Our results highlight a central role of integrins in the ECM modulation of spine dynamics. In particular, CSPG removal enhanced activation of the integrin $\beta 1$ subunit and triggered phosphorylation of FAK at Y397, which couples FAK to several signaling pathways. Slices treated with ChABC showed higher density of active $\beta 1$-integrins and phosphorylated FAK mainly at synaptic sites (as suggested by colocalization of phosphorylated FAK with PSD-95), without changes in protein expression level. ChABC-mediated enhancement of spine dynamics was prevented with a functional $\beta 1$-integrin blocking antibody. Thus, CSPGs restrict spine dynamics by interfering with the $\beta 1$ integrin-mediated activation of downstream events inside dendritic spines that are likely to promote actin rearrangements. Previous studies revealed an interaction between $\beta 1$-integrins and CSPGs (Wu et al., 2002; Tan et al., 2011). The $\beta 1$-integrin subunit has previously been implicated in the regulation of dendritic arborization and synapse density in the postnatal hippocampus (Warren et al., 2012). Integrin activation in cultured hippocampal neurons via application of RGD peptides, an "arginine-glycine-aspartic acid" amino acid motif found on many integrin ligands, was reported to increase the number and length of dendritic spines (Shi and Ethell, 2006) through activation of NMDA receptors and of the CaMKII pathway. Interesting, no RGD motif has been identified on CSPGs, suggesting a different mechanism of integrin activation. The lack of RDG motif together with the absence of blockade of SHPs formation by NMDA antagonists in our experiment, contrast with these previous observations and suggest the triggering of a different form of structural plasticity by ChABC treatment. Other studies demonstrated a role for $\beta 1$-integrins in the stabilization of long-term potentiation (LTP) (Chan et al., 2006; Huang et al., 2006; Kramár et al., 2006). Interestingly, knock-out mice for brevican or neurocan display similar LTP impairment (Zhou et al., 2001; Brakebusch et al., 2002), and ChABC-mediated CSPG digestion reduced LTP in acute slices (Bukalo et al., 2001). Thus, CSPGs might play a fundamental role in unmasking a cryptic binding motif that activates integrins and initiates both functional and structural plasticity. These two forms of plasticity eventually converge to promote reorganization of neuronal circuits after CNS dysfunction.

Recent findings identify a similar role for other inhibitory molecules in restricting structural plasticity of dendritic spines. Among others, the myelin associated inhibitory molecule Nogo-A and its NgR1 receptor (Nogo-66 receptor 1) have recently been shown to control spine density and morphology (Pradhan et al., 2010) as well as synaptic plasticity (Lee et al., 2008). Interestingly, some Nogo-A inhibitory effects on axonal outgrowth are exerted through integrin inactivation ( $\mathrm{Hu}$ and Strittmatter, 2008), and NgR1 and NgR3 have recently been identified as receptors for CSPGs (Dickendesher et al., 2012). Together, these findings suggest an interesting mechanism for convergence of multiple inhibitory signaling pathways on dendritic spine structural plasticity that will be of major interest for further study in the context of CNS plasticity in health and trauma.

The most surprising finding of our study is that local perisynaptic digestion of CSPGs that preserved PNN integrity induced a similar enhancement in the structural plasticity of spines as was seen with global ChABC treatment. Most previous research aiming at understanding the mechanisms through which ChABC promotes structural and functional plasticity in the adult CNS has focused on PNNs implicated in the stabilization of synapses, neuroprotection, and control of ion homeostasis around fastspiking parvalbumin interneurons (Wang and Fawcett, 2012). PNN density is reduced after behavioral or pharmacological enhancement of plasticity (Sale et al., 2007; Harauzov et al., 2010), while adult mice lacking cartilage link-1 protein, essential for the functional organization of CSPGs into PNNs, show persistent plasticity (Carulli et al., 2010). Our results strongly support a parallel role for diffused perisynaptic CSPGs in the local control of spine structural plasticity. It is tempting to speculate that the beneficial effects observed after in vivo ChABC treatment may rely on the digestion of both forms of ECM. While the first may modify the physiology of parvalbumin interneurons and surrounding circuits (Dityatev et al., 2007), perisynaptic CSPG digestion may allow structural synaptic changes to occur. Our observation that ChABC treatment increased spine mobility and induced filopodia-like protrusions, two landmarks of immature neuronal networks, is particularly relevant in this context. While a previous study showed that these protrusions can appear in response to glutamate spillover (Richards et al., 2005), our work shows that they can also be induced by modulation of integrin signaling, and may therefore represent a convergent substrate for multiple plasticity-inducing signals. Although the functional meaning of these protrusions remains to be fully explored, they appear to be long-lasting as they were maintained for several hours, in contrast to cholinergically induced protrusions (Schätzle et al., 2011).

Together, our results underline the role of perisynaptic CSPGs in the control of dendritic spine dynamics through the restriction of $\beta 1$-integrin activation and signaling at synaptic sites. Our observations reveal a possible mechanism through which ChABC treatment enhances structural plasticity of neuronal circuits. Thus far, most attention has been focused on PNNs as the main target of ChABC and therefore the main player in the restriction of plasticity promoted by this treatment. Our finding that PNN digestion is not involved in the observed effects offers an alternative mechanism for this therapeutic strategy in the treatment of CNS trauma.

\section{References}

Boyer C, Schikorski T, Stevens CF (1998) Comparison of hippocampal dendritic spines in culture and in brain. J Neurosci 18:5294-5300. Medline Bradbury EJ, Moon LD, Popat RJ, King VR, Bennett GS, Patel PN, Fawcett JW, McMahon SB (2002) Chondroitinase ABC promotes functional recovery after spinal cord injury. Nature 416:636-640. CrossRef Medline

Brakebusch C, Seidenbecher CI, Asztely F, Rauch U, Matthies H, Meyer H, Krug M, Böckers TM, Zhou X, Kreutz MR, Montag D, Gundelfinger ED, Fässler R (2002) Brevican-deficient mice display impaired hippocampal CA1 long-term potentiation but show no obvious deficits in learning and memory. Mol Cell Biol 22:7417-7427. CrossRef Medline

Brückner G, Grosche J, Hartlage-Rübsamen M, Schmidt S, Schachner M (2003) Region and lamina-specific distribution of extracellular matrix 
proteoglycans, hyaluronan and tenascin- $\mathrm{R}$ in the mouse hippocampal formation. J Chem Neuroanat 26:37-50. CrossRef Medline

Bukalo O, Schachner M, Dityatev A (2001) Modification of extracellular matrix by enzymatic removal of chondroitin sulfate and by lack of tenascin-R differentially affects several forms of synaptic plasticity in the hippocampus. Neuroscience 104:359-369. CrossRef Medline

Carulli D, Pizzorusso T, Kwok JC, Putignano E, Poli A, Forostyak S, Andrews MR, Deepa SS, Glant TT, Fawcett JW (2010) Animals lacking link protein have attenuated perineuronal nets and persistent plasticity. Brain 133:2331-2347. CrossRef Medline

Chan CS, Weeber EJ, Zong L, Fuchs E, Sweatt JD, Davis RL (2006) $\beta 1$ integrins are required for hippocampal AMPA receptor-dependent synaptic transmission, synaptic plasticity, and working memory. J Neurosci 26:223-232. CrossRef Medline

Cho S, Wood A, Bowlby MR (2007) Brain slices as models for neurodegenerative disease and screening platforms to identify novel therapeutics. Curr Neuropharmacol 5:19-33. CrossRef Medline

Deepa SS, Carulli D, Galtrey C, Rhodes K, Fukuda J, Mikami T, Sugahara K, Fawcett JW (2006) Composition of perineuronal net extracellular matrix in rat brain: a different disaccharide composition for the netassociated proteoglycans. J Biol Chem 281:17789-17800. CrossRef Medline

De Simoni A, Griesinger CB, Edwards FA (2003) Development of rat CA1 neurones in acute versus organotypic slices: role of experience in synaptic morphology and activity. J Physiol 550:135-147. CrossRef Medline

Dickendesher TL, Baldwin KT, Mironova YA, Koriyama Y, Raiker SJ, Askew KL, Wood A, Geoffroy CG, Zheng B, Liepmann CD, Katagiri Y, Benowitz LI, Geller HM, Giger RJ (2012) NgR1 and NgR3 are receptors for chondroitin sulfate proteoglycans. Nat Neurosci 15:703-712. CrossRef Medline

Dityatev A, Brückner G, Dityateva G, Grosche J, Kleene R, Schachner M (2007) Activity-dependent formation and functions of chondroitin sulfate-rich extracellular matrix of perineuronal nets. Dev Neurobiol 67:570-588. CrossRef Medline

Frischknecht R, Gundelfinger ED (2012) The brain's extracellular matrix and its role in synaptic plasticity. Adv Exp Med Biol 970:153-171. CrossRef Medline

Gähwiler BH, Capogna M, Debanne D, McKinney RA, Thompson SM (1997) Organotypic slice cultures: a technique has come of age. Trends Neurosci 20:471-477. CrossRef Medline

Galtrey CM, Fawcett JW (2007) The role of chondroitin sulfate proteoglycans in regeneration and plasticity in the central nervous system. Brain Res Rev 54:1-18. CrossRef Medline

García-Alías G, Fawcett JW (2012) Training and anti-CSPG combination therapy for spinal cord injury. Exp Neurol 235:26-32. CrossRef Medline

Gogolla N, Caroni P, Lüthi A, Herry C (2009) Perineuronal nets protect fear memories from erasure. Science 325:1258-1261. CrossRef Medline

Harauzov A, Spolidoro M, DiCristo G, De Pasquale R, Cancedda L, Pizzorusso T, Viegi A, Berardi N, Maffei L (2010) Reducing intracortical inhibition in the adult visual cortex promotes ocular dominance plasticity. J Neurosci 30:361-371. CrossRef Medline

Härtig W, Derouiche A, Welt K, Brauer K, Grosche J, Mäder M, Reichenbach A, Brückner G (1999) Cortical neurons immunoreactive for the potassium channel Kv3.1b subunit are predominantly surrounded by perineuronal nets presumed as a buffering system for cations. Brain Res 842:15-29. CrossRef Medline

Hensch TK (2005) Critical period plasticity in local cortical circuits. Nat Rev Neurosci 6:877-888. CrossRef Medline

Hu F, Strittmatter SM (2008) The N-terminal domain of Nogo-A inhibits cell adhesion and axonal outgrowth by an integrin-specific mechanism. J Neurosci 28:1262-1269. CrossRef Medline

Huang Z, Shimazu K, Woo NH, Zang K, Müller U, Lu B, Reichardt LF (2006) Distinct roles of the $\beta 1$-class integrins at the developing and the mature hippocampal excitatory synapse. J Neurosci 26:11208-11219. CrossRef Medline

Knudsen EI (2004) Sensitive periods in the development of the brain and behavior. J Cogn Neurosci 16:1412-1425. CrossRef Medline

Kramár EA, Lin B, Rex CS, Gall CM, Lynch G (2006) Integrin-driven actin polymerization consolidates long-term potentiation. Proc Natl Acad Sci U S A 103:5579-5584. CrossRef Medline

Kwok JC, Dick G, Wang D, Fawcett JW (2011) Extracellular matrix and perineuronal nets in CNS repair. Dev Neurobiol 71:1073-1089. CrossRef Medline
Lee H, Raiker SJ, Venkatesh K, Geary R, Robak LA, Zhang Y, Yeh HH, Shrager P, Giger RJ (2008) Synaptic function for the Nogo-66 receptor NgR1: regulation of dendritic spine morphology and activity-dependent synaptic strength. J Neurosci 28:2753-2765. CrossRef Medline

Michaluk P, Wawrzyniak M, Alot P, Szczot M, Wyrembek P, Mercik K, Medvedev N, Wilczek E, De Roo M, Zuschratter W, Muller D, Wilczynski GM, Mozrzymas JW, Stewart MG, Kaczmarek L, Wlodarczyk J (2011) Influence of matrix metalloproteinase MMP-9 on dendritic spine morphology. J Cell Sci 124:3369-3380. CrossRef Medline

Mitra SK, Hanson DA, Schlaepfer DD (2005) Focal adhesion kinase: in command and control of cell motility. Nat Rev Mol Cell Biol 6:56-68. CrossRef Medline

Miyata S, Komatsu Y, Yoshimura Y, Taya C, Kitagawa H (2012) Persistent cortical plasticity by upregulation of chondroitin 6-sulfation. Nat Neurosci 15:414-422, S1-S2. CrossRef Medline

Moon LD, Asher RA, Rhodes KE, Fawcett JW (2001) Regeneration of CNS axons back to their target following treatment of adult rat brain with chondroitinase ABC. Nat Neurosci 4:465-466. CrossRef Medline

Mortillo S, Elste A, Ge Y, Patil SB, Hsiao K, Huntley GW, Davis RL, Benson DL (2012) Compensatory redistribution of neuroligins and $\mathrm{N}$-cadherin following deletion of synaptic beta1-integrin. J Comp Neurol 520:2041-2052. CrossRef Medline

Muller D, Buchs PA, Stoppini L (1993) Time course of synaptic development in hippocampal organotypic cultures. Brain Res Dev Brain Res 71: 93-100. Medline

Oray S, Majewska A, Sur M (2004) Dendritic spine dynamics are regulated by monocular deprivation and extracellular matrix degradation. Neuron 44:1021-1030. CrossRef Medline

Pinkstaff JK, Detterich J, Lynch G, Gall C (1999) Integrin subunit gene expression is regionally differentiated in adult brain. J Neurosci 19: 1541-1556. Medline

Pizzorusso T, Medini P, Berardi N, Chierzi S, Fawcett JW, Maffei L (2002) Reactivation of ocular dominance plasticity in the adult visual cortex. Science 298:1248-1251. CrossRef Medline

Pradhan AD, Case AM, Farrer RG, Tsai SY, Cheatwood JL, Martin JL, Kartje GL (2010) Dendritic spine alterations in neocortical pyramidal neurons following postnatal neuronal Nogo-A knockdown. Dev Neurosci 32:313320. CrossRef Medline

Richards DA, Mateos JM, Hugel S, de Paola V, Caroni P, Gähwiler BH, McKinney RA (2005) Glutamate induces the rapid formation of spine head protrusions in hippocampal slice cultures. Proc Natl Acad Sci U S A 102:6166-6171. CrossRef Medline

Sale A, Maya Vetencourt JF, Medini P, Cenni MC, Baroncelli L, De Pasquale R, Maffei L (2007) Environmental enrichment in adulthood promotes amblyopia recovery through a reduction of intracortical inhibition. Nat Neurosci 10:679-681. CrossRef Medline

Schätzle P, Ster J, Verbich D, McKinney RA, Gerber U, Sonderegger P, Mateos JM (2011) Rapid and reversible formation of spine head filopodia in response to muscarinic receptor activation in CA1 pyramidal cells. J Physiol 589:4353-4364. Medline

Shi Y, Ethell IM (2006) Integrins control dendritic spine plasticity in hippocampal neurons through NMDA receptor and $\mathrm{Ca}^{2+} /$ calmodulindependent protein kinase II-mediated actin reorganization. J Neurosci 26:1813-1822. CrossRef Medline

Tan CL, Kwok JC, Patani R, Ffrench-Constant C, Chandran S, Fawcett JW (2011) Integrin activation promotes axon growth on inhibitory chondroitin sulfate proteoglycans by enhancing integrin signaling. J Neurosci 31:6289-6295. CrossRef Medline

Verkuyl JM, Matus A (2006) Time-lapse imaging of dendritic spines in vitro. Nat Protoc 1:2399-2405. CrossRef Medline

Wang D, Fawcett J (2012) The perineuronal net and the control of CNS plasticity. Cell Tissue Res 349:147-160. CrossRef Medline

Wang XB, Bozdagi O, Nikitczuk JS, Zhai ZW, Zhou Q, Huntley GW (2008) Extracellular proteolysis by matrix metalloproteinase-9 drives dendritic spine enlargement and long-term potentiation coordinately. Proc Natl Acad Sci U S A 105:19520-19525. CrossRef Medline

Warren MS, Bradley WD, Gourley SL, Lin YC, Simpson MA, Reichardt LF, Greer CA, Taylor JR, Koleske AJ (2012) Integrin betal signals through Arg to regulate postnatal dendritic arborization, synapse density, and behavior. J Neurosci 32:2824-2834. CrossRef Medline

Wu Y, Chen L, Zheng PS, Yang BB (2002) $\beta 1$-Integrin-mediated glioma cell adhesion and free radical-induced apoptosis are regulated by binding to a 
C-terminal domain of PG-M/versican. J Biol Chem 277:12294-12301. CrossRef Medline

Zhou XH, Brakebusch C, Matthies H, Oohashi T, Hirsch E, Moser M, Krug
M, Seidenbecher CI, Boeckers TM, Rauch U, Buettner R, Gundelfinger ED, Fässler R (2001) Neurocan is dispensable for brain development. Mol Cell Biol 21:5970-5978. CrossRef Medline 